Original article

\title{
Reviewing the measurement methods for Green Development in Cities - a proposal for Polish cities
}

\author{
Agnieszka Świgost-Kapocsi \\ Institute of Geography and Spatial Management, Faculty of Geography and Geology, Jagiellonian University in Krakow, \\ Gronostajowa Str. 7, 30-387 Krakow, Poland \\ E-mail address: agnieszka.swigost@doctoral.uj.edu.pl \\ ORCID iD: https://orcid.org/0000-0002-3229-0271
}

\begin{abstract}
The issues of sustainable and green development is becoming more important, both in scientific analyses and in city policies. The aim of this article was to attempt to create The Green Polish Cities Index. The Index consists of two main parts - Sustainable Development and Green Development, and was based on a review of previous indices and the OECD typology - the PSR (pressure-state-response) model. The article compares and critically analyzes 6 indices used by the European Environment Agency, OECD or other European Units. The selection of indices was connected with a wide application and the diversity of variables used. In total, 226 variables were analysed. Due to a lack of comparative research for Polish cities, The Green Polish Cities Index was constructed. The Index consists of 31 variables representing the most important dimensions of a green and sustainable city. The availability of data and specific conditions of Polish cities were taken into account. An overview of indices and preparation of The Green Polish Cities Index led to the conclusion that implementation of the green city idea under Polish conditions requires, amongst other things, greater cooperation between the Central Statistical Office, universities and city decision-makers.
\end{abstract}

KEY WORDS: Green Development, Sustainable City, The Green Polish Cities Index, the PSR model

ARTICLE HISTORY: received 21 April 2020; received in revised form 4 August 2020; accepted 13 August 2020

\section{Introduction}

The issue of sustainable development in cities is becoming more and more important, both in scientific analyses and in development policy. The requirments are formulated at both the national (in Poland - National Urban Policy) and international level (including the European Union, OECD, UNICEF). The idea of sustainable development is based on a statement that urban consumption should not exceed environmental resources, which in the future will result in meeting the needs of future generations (The European Commission, 2018, KENNEDY ET AL., 2007). One of the dimensions of sustainable development, which emphasizes the development of green areas and pro-ecological activities, is green development. The name 'green city' does not only refer to centres with the largest area of parks and recreational areas, but mainly to those that implement a policy based on green development in their strategy. This issue broadly encompasses the accessibility of green areas, financing activities within green areas, environmental education, as well as the awareness of residents and the level of their involvement in the idea of green development (ADAMS, 2008).

The advantages of green areas in cities are widely known. In addition to environmental and ecological functions they facilitate an improvement in aerosanitary conditions, lower temperature, provide rainwater infiltration, and noise reduction (PAquet eT AL., 2013; Khalil, 2014). Attention is 
increasingly paid to their importance in the social and health dimensions by reducing stress, improving well-being, the possibility of rest or to spend time together and to make new contacts (KUO, 2011; HILLSDON ET AL., 2006; MYTTON ET AL., 2012; PESCHARDT ET AL., 2012).

The research in Polish cities lacks a comparison in the field of sustainable cities and green development. Among others, FoGEL (2007), HULICKA (2015), CZERWIENIEC \& LEWIŃSKA (2000) and MiERZEJEWSKA (2008) draw attention to this fact. The research carried out, for example, by GoDZINA (2015), ŚWIERCZ (2011), the Ministry of Investment and Development (WYSZKOWSKI, 2018), Association of Polish Cities (the portal of Local Government Analysis System) or Arcadis (BORYS, 2017) is largely based on limited data, or it focuses on one city or only on selected elements of a sustainable city and its green development. Poland or its selected cities (mainly Warsaw) can be found in global rankings, e.g. European Green City Index or Green Growth Indicators OECD. The lack of possibilities for comparing cities in this field, as well as a lack of data collection by public statistics units, may indicate a low awareness of the importance of the topic of sustainable cities and green development. According to that, actions taken at the scale of an individual city seem to be significant.

The aim of this article was to attempt to create The Green Polish Cities Index. This Index may facilitate the management of green areas and will allow both residents and local authorities to pay attention to the growing needs of sustainable development. While constructing the Index, the availability of data and the specific conditions that characterise Polish cities (i.e. forms of financing projects or major environmental problems) were taken into account. The Index consists of two main parts - sustainable development and green development, and it was based on a review of used indices and the OECD typology - the PSR (pressurestate-response) model. The Index can be used for different sized citiesand to create a ranking of Polish cities, but its main goal is to draw the attention of local authorities to the problem of sustainable development and to encourage individual research in this area.

The article compares and critically analyses the existing indices in this field. The selection of indices was dictated by their widespread use and the diversity of the applied variables. The reviewed indices, implemented by international government units, focus to a large extent on the comparative assessment of European cities, and less often on the identification of factors shaping the examined state. In this context, the Index presented in the article is different from previously used indices.

\section{The construction method for The Green Polish Cities Index}

The construction of The Green Polish Cities Index took place in two stages. In the first stage, indices presenting the concept of sustainable development and green development were compared. This enabled the separation of the dimensions of a sustainable city and variables which served to construct The Green Polish Cities Index. In addition, the PSR (pressure-state-response) model was used (OECD 1993, 1998). Pressure indicators are those indicators describing the pressure imposed on the natural environment (e.g. consumption of resources, development of infrastructure). State indicators are the indicators related to the current state of the environment, while (social) response indicators describe changes in the environment resulting from activities or implemented policies (BOYD, 1997; DELFT, 1997; ROTMANS, 1997; RODENBURG ET AL., 2001). The choice of variables forming The Green Polish Cities Index was dictated by the OECD criteria (1993, 1998), i.e. policy relevance and utility for users, analytical soundness, measurability (Table 1).

Table 1. Criteria for Indicator Selection (PSR model) (Source: own elaboration based on OECD, 1993)

\begin{tabular}{|l|ll|}
\hline \multicolumn{1}{|c|}{ Dimension } & \multicolumn{1}{|c|}{ Criteria for indicators/data } \\
\hline Policy relevance and & 1. & representativeness \\
utility for users & 2. & simplicity (easy to interpret and able to show trends over time) \\
& 3. responding to changes \\
& 4. comparability (in the international, national and regional dimension) \\
& 5. reference value \\
\hline Analytical soundness & 6. theoretically well founded \\
& 7. based on international standards \\
\hline Measurability & 9. referred to economic models, forecasting and information systems \\
& 10. good quality \\
& 11. up- to- date (regular intervals in accordance with reliable procedures) \\
\hline
\end{tabular}


The PSR model has been updated and modified many times, e.g. by the TARGET group (Tool to Assess Regional and Global Environmental and health Targets for Sustainability) and used as the PSIR model (pressure-state-impact-response framework) or by The European Environmental Agency (EEA) as the DPSIR model, with D for 'driver' indicators (ROTMANS ET AL., 1997; KLATTE, 1997).

The following indices presenting the concept of a sustainable city (Table 2) were analysed: EEA Urban Metabolism Framework (European Environment Agency), European Green City Index (the Economist Intelligence Unit), The Green Growth Indicators (OECD), Reference Framework for Sustainable Cities (RFSC) and Urban Sustainable Indicators (European Foundation for the Improvement of Living and Working Conditions), as well as the one for green development: Urban Economic Indicators for Green Development in Cities (URGE).

The first analysed index - EEA Urban Metabolism Framework Index was implemented by the European Environment Agency. This index consists of 15 variables representing four dimensions (urban flows, urban patterns, urban drivers and urban quality). The objective of the European Environment Agency is a bit wider than the idea of a sustainable city and it refers to the concept of Urban Metabolism, paying special attention to dependencies and flows between the environment and the urban system (MINX ET AL., 2011).
The European Green City Index is an index used to assess sustainable development in 30 European cities. Experts from the Economist Intelligence Unit, in cooperation with Siemens, developed 30 variables representing the state of cities in eight such thematic groups of greenhouse gas emissions, energy consumption, waste management and transport. The assessment was carried out on the basis of both quantitative (e.g. $\mathrm{CO}_{2}$ emissions) and qualitative variables (e.g. Green management - An assessment of the management of environmental issues and commitment to achieving an international environmental standard). In 2012, this index was used to assess over 120 cities in the world (SHIELDS, 2009; SUMNER, 2012).

In 2017, the OECD published a list of Green Growth Indicators which served to co-create the policy of countries in order to improve the quality of life in cities. The 29 key variables represent 5 groups, including natural environment, socioeconomic and political conditions. Among them, there are also such variables as the amount of taxes involved in environmental protection or the degree of land transformation (from natural state to artificial state). In addition, 35 detailed variables clarifying the aforementioned issues were added to the main variables. Apart from the list of variables, the OECD suggests a way to monitor data and the level of their availability (OECD, 2017).

Table 2. Dimensions of the Sustainable City (Source: own elaboration)

\begin{tabular}{|c|c|c|c|c|c|c|c|}
\hline \multirow[b]{2}{*}{ Index Name } & \multirow[b]{2}{*}{ Organization } & \multicolumn{5}{|c|}{ Dimension } & \multirow[b]{2}{*}{ 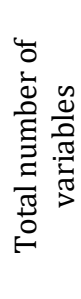 } \\
\hline & & 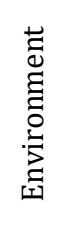 & 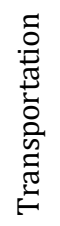 & 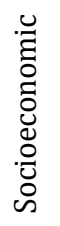 & 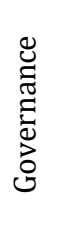 & 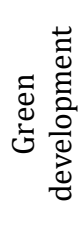 & \\
\hline $\begin{array}{l}\text { EEA Urban Metabolism } \\
\text { Framework }\end{array}$ & European Environment Agency & 7 & 3 & 2 & 0 & 3 & 15 \\
\hline European Green City Index & the Economist Intelligence Unit & 15 & 2 & 1 & 11 & 1 & 30 \\
\hline Green Growth Indicators & OECD & 36 & 0 & 17 & 8 & 3 & 64 \\
\hline $\begin{array}{l}\text { Reference Framework for } \\
\text { Sustainable Cities }\end{array}$ & RFSC & 8 & 5 & 16 & 0 & 5 & 34 \\
\hline Urban Sustainable Indicators & $\begin{array}{l}\text { European Foundation for the Improvement of } \\
\text { Living and Working Conditions }\end{array}$ & 19 & 1 & 9 & 0 & 3 & 32 \\
\hline $\begin{array}{l}\text { Urban Economic Indicators for } \\
\text { Green Development in Cities* }\end{array}$ & $\begin{array}{l}\text { Development of Urban Green Spaces to Improve } \\
\text { the Quality of Life in Cities and Urban Regions }\end{array}$ & 7 & 0 & 28 & 16 & - & 51 \\
\hline \multicolumn{2}{|l|}{ Total } & 92 & 11 & 73 & 35 & 15 & 226 \\
\hline
\end{tabular}

*Urban Economic Indicators for Green Development in Cities refers entirely to the idea of green development 
The Reference Framework for Sustainable Cities (RFSC), is a tool developed with reference to the Leipzig Charter of Sustainable European Cities introduced in 2007. The index consists of 34 main variables representing the following dimensions: economic, environmental and social. Moreover, 300 additional variables were developed, making the tool very flexible and allowing for a wide range of use by European city authorities (VAN DIJKEN ET AL., 2012).

In 1998, the European Foundation for the Improvement of Living and Working Conditions developed the Urban Sustainable Indicators index, which directly refers to the objectives of the Charter of European Sustainable Cities and Towns (Aarlborg Commitments). The Index consists of 32 variables representing issues related to environmental pollution (to a large extent climate changes and air pollution), waste management, social dimensions (e.g. housing, education). As in the case of the European Green City Index, the degree of involvement of residents in city activities was taken into account. Only quantitative variables were used, but it was possible to add unique variables representing the examined cities (MEGA \& PEDERSEN, 1998).

The only Index referring exclusively to the idea of the green city is the Urban Economic Indicator for Green Development in Cities, developed in 2001 as part The Development of Urban Green Spaces to Improve the Quality of Life in Cities and Urban Regions (URGE) Project. The aim of the URGE project was to develop a methodology to improve the management of green areas in cities of the European Union. The Index proposed by the research team consists of 51 variables, in 4 dimensions: socioeconomy, environment, finance and merit. The structure of the Index corresponds to the structure of the OECD indices, taking into account pressure indicators, state indicators and response indicators (RoDENBURG ET AL., 2001).

\section{Dimensions of the Sustainable City}

A common feature of all the indices analysed is the application of a multidimensional approach to the measurement of sustainable development. Each of the examined indices consists of a series of variables covering various thematic fields. The analysis includes five dimensions of a sustainable city (Table 2). The review of sustainable development indices shows that most of them refer to the diverse impact on the environment, socio-economic and political conditions. Despite the frequent allocation of transport to the environmental dimension, it was decided to separate it from the environmental part due to the nature of the variables which mainly take the dimension of transport preferences, and not the direct impact of means of transport on the environment.

It should be noted that in dimensions, the type and number of variables used was different. In addition, the structure of the discussed indices is diverse, and results from the purpose and theoretical scope of individual analyses.

From the analysed thematic groups of a sustainable city, the largest number of variables was used for the environmental dimension (Table 2). This dimension includes pro-ecological activities. Most variables, however, refers to the degree of environmental pollution. In this group, most attention (one fifth of all variables) was paid to air pollution. A lot of attention (20\% of variables) is also concentrated on energy efficiency and the level of use of renewable sources. All described indices also use the variables concerning waste - its amount and the degree of recycling. An interesting example is the OECD Index which refers to the number of patents issued relating to environmental protection and those which take into account biotic conditions (e.g. species diversity).

Variables in the area of transport ( 6 out of 11) mostly refer to transport preferences of residents (percentage of residents using a car, public transport, bicycle and walking). This variable was used in 3 indices (European Green City Index, Reference Framework for Sustainable Cities and Urban Sustainable Indicators). In addition, the quality of public transport (e.g. length of the network), bicycle infrastructure or average travel time and travel costs in various variants were analysed.

In the socio-economic dimension (Table 2), the analysed variables concerned such thematic groups as labour market, poverty or barriers related to access to education, decent housing, health protection and a sense of security. In five cases, reference was made to general conditions such as population, population density or life expectancy. One third of the variables concerned the economic situation of a country/city. In this respect, variables such as GDP, price index or value of exports were used.

A clearly marked group, especially in the case of the European Green City Index, is governance. In the discussed index, all variables in this scope are of a qualitative character and concern the evaluation of policies and strategies in the area of pollution reduction, increase of energy efficiency, recycling and spatial planning. In the case of OECD, emphasis was placed on finances and the amount of taxes relating to environmental (ecological) issues.

Green development is an issue that is a part of the sustainable city objective but it focuses on green areas and pro-ecological activities (ADAMS, 
2008). All of the indices described present this issue in a different dimension. A third of the variables analysed from this group concerned the use of urban land. Three indices (EEA Urban Metabolism Framework, Reference Framework for Sustainable Cities and Urban Sustainable Indicators) directly refer to green areas - their contribution to the city area and accessibility for residents (Green space access). Also in three indices (European Green City Index, Reference Framework for Sustainable Cities and $O E C D$ ), attention was focused on the extent to which citizens can participate in environmental decision-making (participation). In addition, an interesting indicator in the field of green development was proposed in the Reference Framework for Sustainable Cities Index which was the Number of schools with environmental education programs.

To complement the considerations of green development, the Index of Urban Economic Indicators for Green Development in Cities was added to the analysis, and it focuses entirely on this issue. The Index was constructed from 51 variables (Table 2). The most developed (of 28 variables) is the socioeconomic dimension, which is divided into variables from the Accessibility group, among others Number of residences within a maximum walking distance of 500 metres from an urban green space, Area of urban green space per resident and the Multifunctionality group where variables concerning the functions of green areas were collected (e.g. Number of products delivered by urban green space per square kilometre of urban green space) and environmental education (e.g. Number of students following some kind of 'green' education as a percentage of the total number of students in the city). In addition, a significant group of variables refers to the advantages associated with green areas (criteria and variables of the merit dimension), among which there are such variables as noise level in the urban green space compared with the noise level outside the green space or related to safety (e.g. Annual number of incidents in a park compared with the annual number of urban incidents). Another dimension is the environment. In this case the number of proposed variables is lower than in the case of previously discussed indices (Table 2). Nevertheless, as in other cases, the authors of the Urban Economic Indicators for Green Development in Cities focus on the level of air pollution or the vvegetated area in green areas. The last group is a dimension related to governance, where there are mainly variables regarding the financing of pro-ecological activities (e.g. Budget for urban green spaces as a percentage of the total urban budget) and the amount of taxes related to green areas.

\section{The Green Polish Cities Index}

On the basis of the analysed indices, and taking into account the specific conditions of Polish cities (i.e. data availability, forms of financing projects or major environmental problems), The Green Polish Cities Index was constructed, consisting of 31 variables assigned to two parts - Sustainable Development and Green Development. The availability of data at the city level in Polish public statistics, is very diverse. The Index mainly includes data that can be obtained in individual city organizational units related to the implementation of the municipality's tasks (e.g. based on planning documents). Moreover, the data included, which is available in public statistics refer to tasks carried out by the poviat or data collected on a local scale by state institutions (air pollution, meteorological data, data of examination committees). Part of the data included is available at both levels and is collected by individual cities and the Central Statistical Office. In addition to the analysis of indices, the OECD typology based on the PSR model was used for the construction of indicators: pressure-state-response (OECD, 1993, 1998), where pressure determines the pressure indicators on the environment, state is the current state, and (social) response refers to actions and policies undertaken (BOYD, 1997; VAN DELFT, 1997; ROTMANS, 1997; RODENBURG ET AL., 2001). All selected variables meet the Criteria for Indicator Selection (Table 1). The author of this article does not focus on the technical side of the aggregation of the presented variables.

The first part of the Index - Sustainable Development can, to a large extent, be used for preliminary assessment of the living conditions of residents. Due to the presence of many indices which allow an in-depth study of sustainable development in the city, the analysis can be used as an overview. The first part of The Green Polish Cities Index consists of 13 variables presenting four dimensions of a sustainable city (Table 3) environment, transport, socio-economic and governance dimensions.

The variables from the environmental dimension concentrate on one of the greatest challenges of Polish cities which is air pollution (OECD Stat) and the problem of a low percentage of waste recycling (according to BDL GUS data, in Poland in 2018 only $29 \%$ of waste was collected selectively). In the transport dimension, the length of the public transport network, bicycle paths and the number of registered cars was compared. The socioeconomic dimension refers to the exclusion of residents due to the lack of access to education, sewage systems and unemployment. The last 
dimension - governance, inspired by the European Green City Index, presents the actions taken by local authorities in the field of air pollution reduction and the increase in the number of so called green transport users. In addition, tax structure in the field of environmental protection and ecology is also assessed.

Table 3. Sustainable Development (Source: own elaboration)

\begin{tabular}{|c|c|c|c|c|}
\hline Dimension & Variable & Index Name & PSR model & Data availability* \\
\hline \multirow{4}{*}{ Environment } & Annual daily emissions of $\mathrm{SO}_{2}$ & $\begin{array}{l}\text { European Green City } \\
\text { Index }\end{array}$ & Pressure & $\begin{array}{l}\text { available in public } \\
\text { statistics }\end{array}$ \\
\hline & Annual daily emissions of $\mathrm{PM}^{10}$ & $\begin{array}{l}\text { European Green City } \\
\text { Index }\end{array}$ & Pressure & $\begin{array}{l}\text { available in public } \\
\text { statistics }\end{array}$ \\
\hline & $\begin{array}{l}\text { Percentage of the population } \\
\text { affected by noise pollution }\end{array}$ & $\begin{array}{l}\text { Urban Sustainable } \\
\text { Indicators }\end{array}$ & Pressure & $\begin{array}{l}\text { available in city } \\
\text { statistics }\end{array}$ \\
\hline & $\begin{array}{l}\text { Recycling rate (percentage of } \\
\text { municipal waste recycled) }\end{array}$ & $\begin{array}{l}\text { Reference Framework } \\
\text { for Sustainable Cities }\end{array}$ & Response & $\begin{array}{l}\text { available in city } \\
\text { statistics }\end{array}$ \\
\hline \multirow{3}{*}{ Transportation } & $\begin{array}{l}\text { Length of the public transport network } \\
\text { (in km per square meter of city area) }\end{array}$ & $\begin{array}{l}\text { EEA Urban Metabolism } \\
\text { Framework }\end{array}$ & Response & $\begin{array}{l}\text { available in city } \\
\text { statistics }\end{array}$ \\
\hline & $\begin{array}{l}\text { Length of cycling lanes (in km per } \\
\text { square meter of city area) }\end{array}$ & $\begin{array}{l}\text { European Green City } \\
\text { Index }\end{array}$ & Response & $\begin{array}{l}\text { available in city } \\
\text { statistics }\end{array}$ \\
\hline & $\begin{array}{l}\text { Number of registered cars per } \\
\text { resident }\end{array}$ & $\begin{array}{l}\text { EEA Urban Metabolism } \\
\text { Framework }\end{array}$ & Response & $\begin{array}{l}\text { available in public } \\
\text { statistics }\end{array}$ \\
\hline \multirow{3}{*}{ Socioeconomic } & $\begin{array}{l}\text { Quality of education (average exam } \\
\text { results) }\end{array}$ & $\begin{array}{l}\text { Green Growth } \\
\text { Indicators }\end{array}$ & State/response & $\begin{array}{l}\text { available in public } \\
\text { statistics }\end{array}$ \\
\hline & Unemployment rate & $\begin{array}{l}\text { EEA Urban Metabolism } \\
\text { Framework }\end{array}$ & State/response & $\begin{array}{l}\text { available in public } \\
\text { statistics }\end{array}$ \\
\hline & $\begin{array}{l}\text { Percentage of dwellings connected } \\
\text { to the sewage system }\end{array}$ & $\begin{array}{l}\text { European Green City } \\
\text { Index }\end{array}$ & State/response & $\begin{array}{l}\text { available in city } \\
\text { statistics }\end{array}$ \\
\hline \multirow{3}{*}{ Governance } & Actions taken to reduce air pollution & - & Response & $\begin{array}{l}\text { available in city } \\
\text { statistics }\end{array}$ \\
\hline & $\begin{array}{l}\text { Actions taken to increase the use of } \\
\text { green transport }\end{array}$ & - & Response & $\begin{array}{l}\text { available in city } \\
\text { statistics }\end{array}$ \\
\hline & $\begin{array}{l}\text { Structure of environmentally } \\
\text { related taxes (by type of tax base) }\end{array}$ & $\begin{array}{l}\text { Green Growth } \\
\text { Indicators }\end{array}$ & Response & $\begin{array}{l}\text { available in city } \\
\text { statistics }\end{array}$ \\
\hline
\end{tabular}

*Data available in public statistics refer to tasks implemented by the poviat or data collected on a local scale by state institutions.

The second part of the Index - Green Development, is aimed at facilitating the management and planning of new green areas and, more broadly, activities related to green development (Table 4). 18 variables were proposed representing the most important elements of the green city - e.g. availability of green areas, environmental dimension, education and management.

The first and most extensive group is the availability of green areas (Table 4). Wider accessibility of green areas is one of the most frequently postulated issues in Polish cities (ŻAKOWSKA, 2017). According to the recommendation of The European Environment Agency (EEA), green areas should be within no more than a 15minute walking distance. This policy has already been introduced in Brussels, Copenhagen and Paris (PoElman, 2016). The government of the United Kingdom indicates a distance of $300 \mathrm{~m}$ from a house as the maximum distance to green areas (BARBOSA ET AL., 2007), while in Berlin, a $6 \mathrm{~m}^{2}$ green area and a $1 \mathrm{~m}^{2}$ playground should be assigned per resident (KABISCH, 2015). In the Index (Table 4), in addition to the varialles used in the
Urban Economic Indicators for the Green Development in Cities (number of residences within a maximum walking distance of 500 meters from the urban green space, number of residences within a maximum public transport travel time of 10 minutes from the urban green space, area of urban green space per resident), two variables concerning the use of urban areas were also proposed - total percentage of built-up areas in the total city area, total percentage of green areas in the total city area. Green areas are understood in accordance with the Nature Conservation Act of April 16, 2004 (JOURNAL OF LAWS OF 2018, item 1614) ${ }^{1}$. Due to the high popularity of family allotments in Polish cities (according to BDL GUS in 2018, their number

1 Green areas are those areas which have a technical infrastructure and its functional buildings, covered with vegetation, performing public functions, in particular parks, green spaces, promenades, boulevards, botanical, zoological and historic gardens, children's playgrounds, cemeteries, greenery next to roads, squares, historic fortifications, buildings, collection points, airports, railway stations and industrial facilities (Act on Nature Conservation of 16 April 2004, Journal of Laws of 2018, item 1614) 
exceeded 900,000), and the growing popularity of social gardens, as well as the specific role of botanical gardens (according to BGCI, these are green areas with, among others, recreational, educational, protective and research functions), it was decided to additionally distinguish this group as a separate variable - total percentage of special green areas (botanical gardens, social gardens, allotments) in the total city area. In addition, due to the relative high percentage of green areas requiring renovation, a variable regarding this issue was proposed in 2017, 65\% of green areas were indicated for renovation to a varying extent in Krakow (KoWALEWSKA ET AL., 2017).

Table 4. Green Development (Source: own elaboration)

\begin{tabular}{|c|c|c|c|c|}
\hline Dimension & Variable & Index Name & $\begin{array}{c}\text { PSR } \\
\text { model }\end{array}$ & $\begin{array}{c}\text { Data } \\
\text { availability* }\end{array}$ \\
\hline \multirow{7}{*}{ Accessibility } & $\begin{array}{l}\text { Number of residences within a maximum walking } \\
\text { distance of } 500 \text { meters from the urban green } \\
\text { space }\end{array}$ & $\begin{array}{l}\text { Urban Economic } \\
\text { Indicators for Green } \\
\text { Development in Cities }\end{array}$ & State & $\begin{array}{l}\text { Available in } \\
\text { city statistics }\end{array}$ \\
\hline & $\begin{array}{l}\text { Number of residences within a maximum public } \\
\text { transport travel time of } 10 \text { minutes from the } \\
\text { urban green space }\end{array}$ & $\begin{array}{l}\text { Urban Economic } \\
\text { Indicators for Green } \\
\text { Development in Cities }\end{array}$ & State & $\begin{array}{l}\text { Available in } \\
\text { city statistics }\end{array}$ \\
\hline & $\begin{array}{l}\text { Total percentage of built-up areas in the total } \\
\text { city area }\end{array}$ & $x_{1}$ & Pressure & $\begin{array}{l}\text { Available in } \\
\text { city statistics }\end{array}$ \\
\hline & $\begin{array}{l}\text { Total percentage of green areas in the total city } \\
\text { area }\end{array}$ & - & State & $\begin{array}{l}\text { Available in } \\
\text { city statistics }\end{array}$ \\
\hline & $\begin{array}{l}\text { Total percentage of special green areas (botanical } \\
\text { gardens, social gardens, allotments) in the total } \\
\text { city area }\end{array}$ & - & State & $\begin{array}{l}\text { Available in } \\
\text { city statistics }\end{array}$ \\
\hline & Area of urban green space per resident & $\begin{array}{l}\text { Urban Economic } \\
\text { Indicators for Green } \\
\text { Development in Cities }\end{array}$ & State & $\begin{array}{l}\text { Available in } \\
\text { city statistics }\end{array}$ \\
\hline & $\begin{array}{l}\text { Total percentage of green or public spaces in } \\
\text { need of improvement }\end{array}$ & $\begin{array}{l}\text { Urban Sustainable } \\
\text { Indicators }\end{array}$ & Response & $\begin{array}{l}\text { Available in } \\
\text { city statistics }\end{array}$ \\
\hline \multirow{3}{*}{ Environment } & $\begin{array}{l}\text { Percentage of trees in the city in relation to city } \\
\text { area }\end{array}$ & $\begin{array}{l}\text { Reference Framework } \\
\text { for Sustainable Cities }\end{array}$ & State & $\begin{array}{l}\text { Available in } \\
\text { city statistics }\end{array}$ \\
\hline & $\begin{array}{l}\text { Percentage of trees in the urban green space in } \\
\text { relation to the urban green space }\end{array}$ & $\begin{array}{l}\text { Urban Economic } \\
\text { Indicators for Green } \\
\text { Development in Cities }\end{array}$ & State & $\begin{array}{l}\text { Available in } \\
\text { city statistics }\end{array}$ \\
\hline & Number of days with a temperature above $25^{\circ} \mathrm{C}$ & $\begin{array}{l}\text { Urban Economic } \\
\text { Indicators for Green } \\
\text { Development in Cities }\end{array}$ & State & $\begin{array}{l}\text { Available in } \\
\text { public statistics }\end{array}$ \\
\hline \multirow{3}{*}{ Education } & $\begin{array}{l}\text { Number of schools with environmental } \\
\text { education programs }\end{array}$ & $\begin{array}{l}\text { Reference Framework } \\
\text { for Sustainable Cities }\end{array}$ & Response & $\begin{array}{l}\text { Available in } \\
\text { city statistics }\end{array}$ \\
\hline & $\begin{array}{l}\text { Funds raised by the city for the green } \\
\text { development projects }\end{array}$ & - & Response & $\begin{array}{l}\text { Available in } \\
\text { city statistics }\end{array}$ \\
\hline & $\begin{array}{l}\text { Costs of research projects with regard to urban } \\
\text { green space per square kilometre of urban } \\
\text { green space }\end{array}$ & $\begin{array}{l}\text { Urban Economic } \\
\text { Indicators for Green } \\
\text { Development in Cities }\end{array}$ & Response & $\begin{array}{l}\text { Available in } \\
\text { city statistics }\end{array}$ \\
\hline \multirow{4}{*}{ Governance } & $\begin{array}{l}\text { Budget for the urban green spaces as a } \\
\text { percentage of the total city budget }\end{array}$ & $\begin{array}{l}\text { Urban Economic } \\
\text { Indicators for Green } \\
\text { Development in Cities }\end{array}$ & Response & $\begin{array}{l}\text { Available in } \\
\text { city statistics }\end{array}$ \\
\hline & $\begin{array}{l}\text { Actual expenditure on the urban green space per } \\
\text { square kilometre of urban green space }\end{array}$ & $\begin{array}{l}\text { Urban Economic } \\
\text { Indicators for Green } \\
\text { Development in Cities }\end{array}$ & Response & $\begin{array}{l}\text { Available in } \\
\text { city statistics }\end{array}$ \\
\hline & $\begin{array}{l}\text { Total number of associations for urban } \\
\text { improvement and quality of life }\end{array}$ & $\begin{array}{l}\text { Urban Sustainable } \\
\text { Indicators }\end{array}$ & Response & $\begin{array}{l}\text { Available in } \\
\text { city statistics }\end{array}$ \\
\hline & $\begin{array}{l}\text { Total percentage of the 'green project' selected } \\
\text { for realization in the participatory budget }\end{array}$ & - & Response & $\begin{array}{l}\text { Available in } \\
\text { city statistics }\end{array}$ \\
\hline $\begin{array}{l}\text { Unique } \\
\text { sustainability }\end{array}$ & $\begin{array}{l}\text { Unique factors or events leading to urban } \\
\text { sustainability with its environmental, social and } \\
\text { economic dimensions }\end{array}$ & $\begin{array}{l}\text { Urban Sustainable } \\
\text { Indicators }\end{array}$ & - & - \\
\hline
\end{tabular}

* Data available in public statistics refer to tasks implemented by the poviat or data collected on a local scale by state institutions. 
The environmental dimension, related to the main functions of urban areas, in contrast to the section on a sustainable city, focuses on the quality of trees in stands and the number of days with high temperatures, which can depict the phenomenon of a urban heat island (Table 4). Another dimension is related to the so-called "green education", which plays an important role in shaping the attitudes of the youngest city dwellers (RODENBURG ET AL., 2001). Moreover, a variable was added here with an emphasis on financing the research and development projects in the field of green development (funds raised by the city for green development projects). The last dimension - governance, apart from the issues concerning the city budget (budget for urban green spaces as a percentage of the total city budget, actual expenditure on the urban green space per square kilometre of the urban green space), raises issues related to the level of resident involvement in pro-ecological activities. This is expressed by the index of the total number of associations for urban improvement and quality of life and the total percentage of the 'green project' selected to realization in the participatory budget. The governance dimension is extremely important, as emphasized by the authors of the index for Urban Economic Indicators for Green Development in Cities, 'The more attention is paid to urban green spaces in urban policies, the more budget will be released for urban green spaces and the higher the quality of urban life will be' (RODENBURG ET AL., 2001: 113-114). Additionally, based on the Urban Sustainable Indicators index, a possibility to indicate unique conditions or solutions applied in the city was aed to The Green Polish Cities Index (unique factors or events leading to urban sustainability with its environmental, social and economic dimensions).

\section{Discussion and conclusions}

Due to the wide diversity of development level of European cities, mainly relative measures are used in the studies of sustainable development and green development - referring to particular conditions. Thus, there is a significant variation in the variables used among the analysed indices. What is more, the issue analysed can be considered from different perspectives, so the variables and indices can also be constructed differently. Some of them (e.g. EEA Urban Metabolism Framework) are based only on a few main variables. For the other indices - e.g. Green Growth Indicators, Urban Economic Indicators for Green Development in Cities, the number of variables and the number of dimensions in which the issue is considered may indicate a deeper analysis of the phenomenon. The diversity of sustainable city measurement methods can also be demonstrated by the type of variables analysed.

The Green Polish Cities Index, created on the basis of a review of the indices and OECD PSR methodology, aims to improve the management of green areas in Polish cities. The measurement of sustainable and green development must be multidimensional and a wide triangulation of methods and indices is needed so that the expertise in question can have a practical value for local and regional policies. In addition, the authors of the OECD PSR model emphasize the simplifications used in this type of research (OECD, 1993). The quantitative analysis of qualitative phenomena, in particular in the area of transport behaviour of residents or their socio-economic conditions, also seems to be problematic. What is more, variables representing the socio-economic dimension are hard to classify into one of the three groups of indicators. The housing situation or the level of education of residents may be considered as the current state (state indicators) and as the result of actions (or lack of actions) on the part of local authorities (response indicators). The authors of the Urban Economic Indicators for Green Development in Cities (RoDEnBURG ET AL., 2001) also drew attention to a similar problem.

The PSR model places a particular emphasis on data quality, its accessibility, regular publications and comparability. Despite the fact that during the selection of variables for The Green Polish Cities Index the authors were mainly guided by their simplicity, there is no certainty that it will be possible to obtain the necessary data for all cities in the regional dimension. A noticeable need is to collect, but also to share, data on sustainable development for Polish cities.

It should be remembered that the proposed variables and criteria cannot be seen as a 'recipe' for a green city. It is obvious that every urban centre has different conditions and specific features. However, basing the policy on reliable data and results will certainly accelerate the achievement of the expected results.

\section{References}

Adams B. 2008. Green Development. Environment and sustainability in a developing world. Taylor \& Francis Group, London, New York.

Barbosa O., Tratalos J., Armsworth P., Davies R., Fuller R., Johnson P., Gaston K. 2007. Who benefits from access to green space? A case study from Sheffield. Landscape and Urban Planning, 83: 187-195. 
Borys T. (ed.). 2017. Ranking polskich miast zrównoważonych. Arcadis, Kraków-Wrocław.

Boyd D. 1997. Why a Course on Indicators for Sustainable Development? Advanced Course on Indicators for Sustainable Urban Development, by IIUE: 21-36.

Czerwieniec M., Lewińska J. 2000. Zieleń $w$ mieście. Instytut Gospodarki Przestrzennej i Komunalnej, Kraków.

Delft Y.V. 1997. An introduction to indicators and monitoring Advanced Study Course on Indicators for Sustainable Urban Development, by IIUE. Nivo.

Fogel A., Fogel P. 2007. Możliwość wykorzystania europejskich wskaźników zrównoważonego rozwoju w planowaniu przestrzennym na szczeblu lokalnym. [in:] M. Kistowski, B. Korwel-Lejkowska (eds.) Waloryzacja środowiska przyrodniczego $w$ planowaniu przestrzennym, Fundacja Rozwoju Uniwersytetu Gdańskiego, Gdańsk-Warszawa: 129-131.

Godzina P. 2015. Tereny zieleni publicznej w kontekście zrównoważonego rozwoju miasta. Prace Geograficzne, 141: 52-72.

Hillsdon M., Panter J., Foster C., Jones A., 2006. The relationship between access and quality of urban green space with population physical activity. Public health, 120: 1127-1132.

Hulicka A. 2015. Miasto zielone - miasto zrównoważone. Sposoby kształtowania miejskich terenów zieleni w nawiązaniu do idei Green City. Prace Geograficzne, 141 73-85.

Indicators for sustainable cities. In-depth Report 12. 2018. Science for Environment Policy. The European Commission DG Environment, Bristol.

Kabisch N. 2015. Urban green space distribution and accessibility in Berlin, Germany. Bulletin of People-Environmental Studies, 42: 7-14.

Kennedy C., Cuddihy J., Engel-Yan J. 2007. The changing metabolism of cities. Journal of Industrial Ecology, 11, 2: 43-59.

Khalil R. 2014. Quantitative Evaluation of Distribution and Accessibility of Urban Green Spaces (Case study: City of Jeddah). International Journal of Geomatics and Geosciences, 4, 3: 526-535.

Klatte E. 1997. European Environment Agency. International Institute for the Urban Environment, Advanced Study Course on Indicators for Sustainable Urban Development.

Kowalewska A. (ed.). 2017. Kierunki rozwoju i zarzadzania terenami zieleni $w$ Krakowie na lata 2017-2030. Wydział Kształtowania Środowiska, Kraków: 204-237.

Kuo F.E. 2011. Parks and Other Green Environments: Essential Components of a Healthy Human Habitat. Australasian Parks and Leisure, 14, 1: 10-12.

Mega V., Pedersen J. 1998. Urban Sustainability Indicators, European Foundation for the Improvement of Living and Working Conditions. EUR-OP, Luxemburg.

Mierzejewska L. 2008. Zrównoważony rozwój miasta: aspekty planistyczne. Biuletyn Instytutu Geografii SpołecznoEkonomicznej i Gospodarki Przestrzennej Uniwersytetu im. Adama Mickiewicza w Poznaniu, Seria Rozwój Regionalny $i$ Polityka Regionalna, 5: 49-70.

Minx J., Felix Creutzig F., Medinger V., Ziegler T., Owen A., Baiocchi G. 2011. Developing a Pragmatic Approach to Assess Urban Metabolism in Europe. A Report to the European Environment Agency. Berlin.
Mytton O., Townsend N., Rutter H., Foster C. 2012. Green space and physical activity: An observational study using Health Survey for England data. Health Place, 18, 5: 1034-1041.

OECD 1993. Core Set of Indicators for Environmental Performance Reviews: A Synthesis Report by the Group on the State of the Environment. OECD Publishing, Paris.

OECD 1998. Towards Sustainable Development: Environmental Indicators. OECD Publishing, Paris.

OECD 2017. Green Growth Indicators 2017. OECD Publishing, Paris.

Paquet C., Orschulok T., Coffee N., Howard N., Hugo G., Taylor A., Adams R., Daniel M. 2013. Are accessibility and characteristics of public open spaces associated with a better cardiometabolic health? Landscape and Urban Planning, 118: 70-78.

Peschardt K., Schipperijn J., Stigsdotter U. 2012. Use of Small Public Urban Green Spaces (SPUGS). Urban Forestry and Urban Greening, 11: 235-244.

Poelman H. 2016. A Walk to the Park? Assessing Access to Green Areas in Europe's Cities. Regional and Urban Policy, European Commission.

Rodenburg C., Baycan-Levent T., Leeuwen E., Nijkamp P. 2001. Urban Economic Indicators for Green Development in Cities. Greener Management International, 36: 105-119.

Rotmans J. 1997. Indicators for Sustainable Development. [in:] J. Rotmans, B. de Vries (eds.) Perspectives on Global Change: The TARGETS Approach, Cambridge University Press, Cambridge: 187-204.

Rotmans J., de Vries B.J.M., van Asselt M.B.A. 1997. Concepts. [in:] J. Rotmans, B. de Vries (eds.) Perspectives on Global Change: The TARGETS Approach, Cambridge University Press, Cambridge: 15-32.

Shields K., Langer H., Watson J., Stelzner K. 2009. European Green City Index: Assessing the environmental impact of Europe's major cities. Siemens AG. Munich, Germany.

Sumner J. (ed.). 2012. The Green City Index, A summary of the Green City Index research series. Siemens AG. Munich, Germany.

Świercz A. 2011. Zieleń miejska w systemie przyrodniczym Kielc - kształtowanie, wskaźniki. Problemy Ekologii Krajobrazu, XXIX: 173-184.

Ustawa o ochronie przyrody. 16 April 2004, Journal of Laws of 2018, item 1614.

Van Dijken K., Dorenbos R., Kamphof R. 2012. The reference framework for sustainable cities (RFSC): Testing results and recommendations. Nicis Institute: Den Haag, The Netherlands.

Wyszkowski K. (ed.). 2018. Zrównoważone miasta. Poprawa jakości powietrza w Polsce 2018. Global Compact Network Poland, Warszawa.

Żakowska M. 2017. Zielone dylematy. [in:] H. Mazur (ed.) Miasto na plus. Eseje o polskich przestrzeniach miejskich, Wysoki Zamek, Kraków: 287-305.

Internet resources:

Botanic Gardens Conservation International https://www.bgci.org (access 08.2020).

Bank Danych Lokalnych Główny Urząd Statystyczny [Local Data Bank Central Statistical Office] https://bdl.stat.gov.pl/ [access 08.2020).

OECD Stathttps://stats.oecd.org (access 08.2020). 